\title{
Mini-Review on the Possible Interconnections between the Gut-Brain Axis and the Infertility-Related Neuropsychiatric Comorbidities
}

\author{
Gabriela Simionescu ${ }^{1,2,3}$, Ovidiu-Dumitru Ilie ${ }^{4}{ }^{-}$, Alin Ciobica ${ }^{4}$, Bogdan Doroftei ${ }^{1,2,3, *}$, \\ Radu Maftei ${ }^{2,3,5}$, Delia Grab ${ }^{1,2}$, Jack McKenna ${ }^{6}$, Nitasha Dhunna ${ }^{7}$, Ioannis Mavroudis ${ }^{8,9}$ \\ and Emil Anton ${ }^{1,2}$ \\ 1 Department of Mother and Child Medicine, Faculty of Medicine, University of Medicine and Pharmacy \\ “Grigore T. Popa”, University Street, No 16, 700115 Iasi, Romania; gabi.ginecologie@gmail.com (G.S.); \\ delianicolaiciuc@yahoo.com (D.G.); emil.anton@yahoo.com (E.A.) \\ 2 Clinical Hospital of Obstetrics and Gynecology “Cuza Voda”, Cuza Voda Street, No 34, 700038 Iasi, Romania; \\ dr.radu.maftei@gmail.com \\ 3 Origyn Fertility Center, Palace Street, No 3C, 700032 Iasi, Romania \\ 4 Department of Research, Faculty of Biology, "Alexandru Ioan Cuza” University, Carol I Avenue, No 11, \\ 700505 Iasi, Romania; ovidiuilie90@yahoo.com (O.-D.I.); alin.ciobica@uaic.ro (A.C.) \\ 5 Department of Morphostructural Sciences, Faculty of Medicine, University of Medicine and Pharmacy \\ “Grigore. T. Popa” Iasi, University Street, No 16, 700115 Iasi, Romania \\ 6 York Hospital, Wigginton Road Clifton, York YO31 8HE, UK; jackscloudinthesky@me.com \\ 7 Mid Yorkshrie Hospitals NHS Trust, Pinderfields Hospital, Wakefield WF1 4DG, UK; \\ n.dhunna@hotmail.co.uk \\ 8 Leeds Teaching Hospitals NHS Trust, Great George St, Leeds LS1 3EX, UK; ioannis.mavroudis@nhs.net \\ 9 Laboratory of Neuropathology and Electron Microscopy, School of Medicine, Aristotle University of \\ Thessaloniki, 54124 Thessaloniki, Greece \\ * Correspondence: bogdan.doroftei@umfiasi.ro
}

Received: 12 May 2020; Accepted: 15 June 2020; Published: 17 June 2020

\begin{abstract}
Both the gut-brain axis (GBA) and the hypothalamic-pituitary-adrenal (HPA) axis remain an intriguing yet obscure network with a strong influence over other systems of organs. Recent reports have sought to describe the multitude of harmful stressors that may impact the HPA axis along with the interconnections between these. This has improved our knowledge of how the underlying mechanisms working to establish homeostasis are affected. A disruption to the HPA axis can amplify the chances of gastrointestinal deficiencies, whilst also increasing the risk of a wide spectrum of neuropsychiatric disorders. Thus, the influence of microorganisms found throughout the digestive tract possess the ability to affect both physiology and behaviour by triggering responses, which may be unfavourable. This is sometimes the case in of infertility. Numerous supplements have been formulated with the intention of rebalancing the gut microflora. Accordingly, the gut flora may alter the pharmacokinetics of drugs used as part of fertility treatments, potentially exacerbating the predisposition for various neurological disorders, regardless of the age and gender.
\end{abstract}

Keywords: microbiome; gastrointestinal; neuropsychiatry; infertility

\section{The Current Understanding of the "Second Brain"}

Following early studies into the relationship between humans and bacteria, attained through a series of microscopic observations [1], came the largest research project dedicated to all-commensal, symbiotic and pathogenic entities three and a half centuries later [2]. In 2008, this Human Microbiome Project (HMP) was launched. The main objective(s) of the initial, or "Jumpstart" phase, were to develop 
new algorithms (libraries with reference sequences), technologies and tools dedicated to the assessment of the intestinal microflora [3].

It has been concluded that all the microorganisms which colonise our body are grouped into four major microbial categories. The gastrointestinal microbiota (GM) exceeds the oral, urogenital and skin microbiota, and even outnumber the total number of the human somatic and germ cells by a factor of 10 [4]. The microbes are spread throughout the entire gastrointestinal tract $[5,6]$, with anaerobic microorganisms sub-divided into three enterotypes: Ruminococcus, Prevotella and Bacteroides [7]. The most abundant bacterial collections are the Firmicutes, Bacteroidetes, Actinobacteria and Verrucomicrobia phyla [8], collectively unifying over 1000 species that have been cultured and analysed phylogenetically [9].

The Integrative Human Microbiome Project (iHMP) then centred its focus on the influence of the gut's flora on transient episodes-more precisely, between eubiosis and dysbiosis. There are three aspects to the second research phase; each aspect is considered in the context of the commensal, enteric bacteria. These phases were (I) pregnancy, delivery method and premature births; (II) irritable bowel syndrome (IBS) and its potential triggers; and finally, (III) the influence of stressors in the pathophysiology of prediabetes [10].

The gastrointestinal microbiota is composed of distinct cell types [11-14] which fulfil key roles [15] in order to prevent a dysbacteriosis. These different cell types initiate specific responses, defining its crucial role in maintaining the integrity of the neurohormonal axes [16].

Even if the concept regarding the two-way path between the intestinal flora and the brain is generally accepted, these relations are still insufficiently understood. The gut-brain axis (GBA) is a dense network which unites a number of fundamental physiological pathways, such as the central nervous system (CNS), the neuro-endocrine and -immune systems as well as the sympathetic and parasympathetic components of the autonomic nervous system (ANS) and the enteric nervous system (ENS). The hypothalamic-pituitary-adrenal (HPA) axis also plays a pivotal role alongside the GBA in many stress-related disorders [17].

Recent findings support the notion of a "personalised microbiome", with an inter-individual variation through a series of endo- and exogenous factors. The commensal microbiota are influenced by interactions with pathogens [18] along with dietary differences [19], and prolonged exposure to medications [20]. The myriad of influencing factors contribute to the formation of the individual human virome [21], as well as the 'gut resistome' or antibiotic resistance [22]. Other factors that can affect the micro-environment include a lack of physical exercise [23], as well as the influence of heritable components [24], and the culmination of these factors promotes transitions of bacteria in different sites along the gut [25].

Apart from the metabolism of the gut microbiota, characterised by a wide variety of metabolites involved in a host's eubiosis $[26,27]$ based on the exogenous supply, these microbial associations as well participate in shaping a newborn's microbiota [28].

\section{Disruptive Factors in Enteric Eubiosis and the Influence on Colonisation in Neonates}

One of the earliest interactions of the foetus with the maternal urogenital microbiota take place once the foeus passes into the birth channel [28].

The colonisation process could actually be initiated in utero; Collado et al. [29] identified that Proteobacteria is the most prevalent phylum in both the placenta as well as the amniotic fluid. Data obtained following the analysis of the meconium suggest a mother-foetal transfer, with infants' microbiota being similar to that found in the colostrum after almost one week. The neonatal microbial communities are influenced by several processes such as preterm deliveries along with the method of delivery.

Aagaard et al. [30] have highlighted the existence of a temporary niche formed during pregnancy, which unites four phyla: Firmicutes, Tenericutes, Proteobacteria, Bacteroidetes and the Fusobacteria genus. While Bifidobacterium, Lactobacillus, Bacteroides and Clostridium are passed via the placenta [31,32], 
Lauder et al. [33] concluded that there are no significant differences between the number of copies following a q-PCR analysis between the placental strains and the negative controls.

However, whether or not the placenta possesses beneficial microorganisms is still under question, mainly because some recent evidences supports the notion of favourable conditions for certain pathogen proliferation-in particular, Group B streptococcus [34].

Stout et al. [35] established that $27 \%$ of the basal plates of placentas possess intracellular bacteria which is, therefore, a possible route for intra-uterine colonisation. The finding of placental intracellular bacteria was found in $54 \%$ of the studied cohort who had a spontaneous preterm delivery, and in only $26 \%$ of term-spontaneous deliveries. There were no major differences in the predisposition for intra-amniotic infections or Group B Streptococcus in preterm births.

Intrauterine infections are known to be a cause of both spontaneous preterm labour (PTL) and/or preterm prolonged rupture of membranes (PPROM) [36,37]. As the bacterial DNA has been detected in $70 \%$ from all the placental tissues, the authors concluded that the placental membranes possess bacteria, but it is not a cause of preterm labour or PPROM [38] following a caesarean section (C-section). On the other hand, no signatures of bacterial DNA have been detected compared with term vaginal deliveries, the positivity being around 50\% [39].

The gestational age of an infant can correlate to the diversity seen in the commensal bacteria that are acquired by the infant, which is suggestive of prenatal influences [40,41]. Interestingly, Hu et al. [42] have concluded that the meconium unites microbial strains, arguing that the mode of birth does not influence the microbial diversity. However, the microbial composition of the meconium was significantly influenced by the maternal diabetes status.

It is intriguing that one of the microbes involved in the metabolism of levodopa in patients with Parkinson's disease has been identified in meconium samples. With a rate of 1 to 5 samples, Enterococcus faecalis has been identified in almost $80 \%$ of all the samples after the meconium has passed within the first two hours [43].

Hansen et al. [44] evaluated the microbiota contained within the meconium, and they found that bacteria was detectable in two-thirds of the meconium samples through the use of fluorescence in situ hybridization (FISH) and 7\% by standard polymerase chain reaction (PCR), while a significant percentage of sterile samples have been defined by a minimum inhibitory concentration (MIC).

Enterococcus, Streptococcus, Staphylococcus, or Propionibacterium were the predominant strains in the umbilical blood cord [43], while in the amniotic fluid the bacterial composition was dominated by species such as Sneathia sanguinegens, Leptotrichia amnionii and an uncharacterised bacteria [45]. Shao et al. [46] have identified that the bacterial composition can be influenced by delivery method, as they demonstrated a disruption to the transmission of the maternal Bacteroides in caesarean sections, with C-sections proving to detriment the Enterococcus, Enterobacter and Klebsiella species.

In addition, preterm infants often receive treatment with antibiotics in order to prevent possible infections, but a recent research article has demonstrated the subsequent existence of resistome as a result of prolonged exposure to various drugs [47], suggesting that an infant's commensal microbiome will be impacted by these antibiotics.

\section{Enteric Microbial Variations in Childhood: The Heritable and Social Components}

Turnbaugh et al. [48] revealed that even monozygotic (MZ) pairs have distinct signatures of commensal microbiota. The stool samples collected were compared to 1095 bacterial communities that are commonly found in the gut and other body habitats, from related and unrelated individuals. In over one million bacterial reads, the $\alpha$-diversity indicated approximately 800 following the analysis of the hypervariable $\mathrm{V} 2$ region.

Goodrich et al. [49] have reproduced an association between the lactic bacteria belonging to the Bifidobacterium, which is usually heritable between the UK twins, and the LCT gene locus, being responsible for the hydrolysation of lactose in the upper GI tract. 
The faecal samples collected from mono (MZ)- and dizygotic (DZ) twin individuals from the United States and South Korea have revealed the existence of a unique microbiome. Based on the sequences obtained following the analysis of the bacterial V2 region, Lee et al. [50] have concluded that this variation seems to be the result of a combination between some temporal and spatial variables.

This hypothesis also applies to a much smaller degree in brothers. In a study conducted by Schloss et al. [51], a metagenomic shotgun analysis of $16 \mathrm{~S}$ rRNA's V3-V5 region has been conducted with the aim of distinguishing the microbial communities of each family member having as reference individuals which live in the same geographic area. Bifidobacterium and Escherichia have been the most dominant strains encountered in all siblings, with the mention that the microbiota of the two-year-old was more similar to her weaned siblings. Twelve operational taxonomic units (OTUs) have been identified within the family, from which four were location specific, belonging to the genus Bacteroides and Subdoligranulum and family Lachnospiraceae.

Recently, Kato et al. [52] revealed the presence of the CC genotype in 1068 Japense adults at rs4988235 and the GG at rs182549, in addition to those previously reported (rs145946881, rs41380347, rs41525747 and rs869051967). They found that there was positive correlation between the CC genotype and a low abundance of Bifidobacterium [53,54]. C/T(-13910) has been mainly reported as the predominant lactase locus in Europeans, while G/A(-22018) in Japanese-Brazilian and Chinese populations [55]. In addition, bathtub water has proved to be a potential vehicle for the bacterial transfer and it is not strictly a mother-to-infant axis.

Odamaki et al. [56] enrolled 21 Japanese individuals from five families and, after the isolation of the faecal and bathtub samples, Bifidobacterium longum was shown to be the most abundant microorganism exchanged between the members, compared with those which do not adopt this tradition. A comparative study conducted by the same author demonstrated that Bifidobacterium longum subsp. longum is present throughout the entire life, regardless of age. Their results suggest that some bacteria are distributed across family members [57].

Laursen et al. [58] have evaluated how early infections, having older brothers or pets could disrupt the normal colonisation of the gut. David Strachan's hygiene hypothesis has been certified in the present study, with the presence of older siblings being positively correlated with the bacterial diversity and richness of Firmicutes and Bacteroidetes or with Faecalibacterium prausnitzii [59]. On the other hand, pets or early infections had less contribution towards the gut flora, without any significant data correlation.

Dill-McFarland et al. [60] have emphasised in his study an attribute acquired as social human beings. The analysis of the faecal samples collected from 177 individuals, from which 94 were spouses and 83 were siblings, revealed that their taxa is more similar and diverse when compared with those of related or unrelated individuals, with the cause-effect relating to dietary habits.

The faecal samples collected over an interval of two years has showed that are no major fluctuations within these communities, being stable throughout the entire study. The only minor difference was in the case of one person after an intervention that required medication, and no foreign or major change regarding species density has been reported [61].

\section{How Is the HPA Axis Influenced?}

A reduction in the host's innate eubiosis triggers a pro-inflammatory cascade [62]. If this state is prolonged it may lead to gastrointestinal disorders [63,64], as well as neurodegenerative [65] or neuropsychiatric disorders [66].

In such cases, the HPA axis exerts an antagonistic effect upon the organism. It has been shown that the patients with a major depressive disorder (MDD) have high serum levels of cortisol [67] and reduced levels of oxytocin [68]. The results obtained in another study, conducted with a similar design to the previous one, provides additional evidence and further consolidates this strong correlation between the brain and the digestive tract [69]. 
There is a lot of controversy regarding the interconnections between the neurological and gastrointestinal disorders $[63,66]$ and even if these disturbances of the central nervous system (CNS) are irremediable, at least the symptoms can be reduced by enhancing the GM.

A number of conventional alternatives have been developed in recent years [70,71], presently being considered the most powerful vehicles for the acquisition of the beneficial microorganisms intended for the reconstruction of the GM (Table 1).

Table 1. The modulatory effects following the administration of probiotics in the regulation of the GBA-HPA axes.

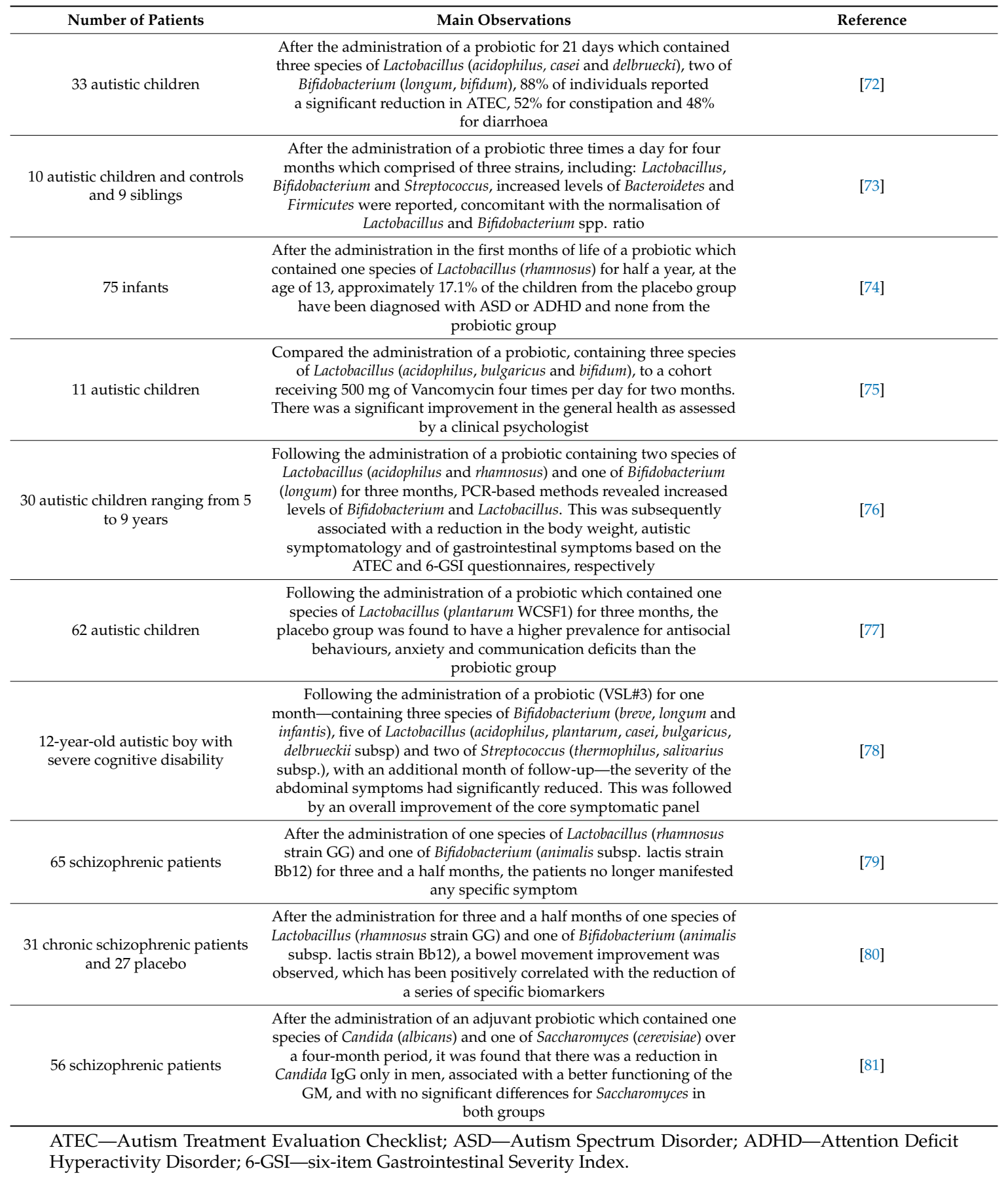

It has been suggested that intestinal microflora may reduce or even inhibit the treatment for infertility [82] and, in parallel, gradually promote neuropsychiatric disorders (Table 2). 
Table 2. Infertility drugs with a known effect to induce pronounced mood fluctuations as a side effect.

\begin{tabular}{|c|c|c|c|}
\hline Type of Drug & Number of Patients & Main Observations & Reference \\
\hline $\mathrm{CC}$ & 50 patients ( 25 couples) & $\begin{array}{l}\text { CC have exacerbated symptoms of PMS in } \\
9 \text { out of } 14 \text { women only (e.g., irritability and } \\
\text { mood swings) }\end{array}$ & [83] \\
\hline $\mathrm{CC}$ & 1 male patient & $\begin{array}{l}\text { The patient in this study was diagnosed } \\
\text { with oligoteratospermia and had received } \\
\text { CC. The treatment culminated in } \\
\text { depressive symptoms for five consecutive } \\
\text { days. After the treatment was discontinued, } \\
\text { it took an additional seven days until he } \\
\text { made a full recovery }\end{array}$ & [84] \\
\hline $\mathrm{CC}$ and $\mathrm{hMG}$ & $\begin{array}{c}454 \text { (139 women who had not } \\
\text { previously taken any drug and } \\
315 \text { who had previously received } \\
\text { medication) }\end{array}$ & $\begin{array}{l}\text { This cross-sectional, self-reported study } \\
\text { concluded that both CC ( } n=162) \text { and hMG } \\
(n=153) \text { act as agonists and could trigger } \\
\text { disorders such as depression according to } \\
\text { the STAI through a disturbance of the HPA } \\
\text { axis. Significant differences were noted } \\
\text { between the groups, with those women } \\
\text { taking either CC or hMG reporting a higher } \\
\text { incidence of psychological effects }\end{array}$ & [85] \\
\hline OC & $\begin{array}{c}34 \text { women }(17 \text { COC and } 17 \\
\text { placebo) }\end{array}$ & $\begin{array}{l}\text { During the seven-day study period, the } \\
\text { COC users displayed more depressive } \\
\text { symptoms when compared to the placebo } \\
\text { cohort according to the CD scale. This was } \\
\text { highlighted by a specific reactivity at the } \\
\text { level of the insular cortex, respectively, the } \\
\text { first one-third and the lowest portion of the } \\
\text { frontal lobe through fMRI both before as } \\
\text { well as during the treatment }\end{array}$ & [86] \\
\hline OC & 76 women ( 38 OC and 38 placebo) & $\begin{array}{l}\text { A significant percentage }(77 \%) \text { of the total } \\
\text { adolescent cohort had one side effect } \\
\text { manifested. Interestingly, the number and } \\
\text { type of side effects were identical in both } \\
\text { the OC and placebo groups after the } \\
\text { completion of CES-D }\end{array}$ & [87] \\
\hline $\mathrm{HC}$ & $\begin{array}{l}2532 \text { women ( } 232 \\
\text { oestrogen-progestin, } 58 \text { progestin } \\
\text { only and } 948 \text { with no treatment) }\end{array}$ & $\begin{array}{l}\text { The use of combined hormone } \\
\text { contraception has been higher in } \\
\text { Caucasians with MDD, while those on } \\
\text { progesterone monotherapy displayed more } \\
\text { hypersomnia, weight gain and a relatively } \\
\text { worse physical functioning. Those with the } \\
\text { COC were singnificantly less depressed } \\
\text { than those in the other two groups } \\
\text { according to the QIDS score }\end{array}$ & [89] \\
\hline $\mathrm{HC}$ & 75,528 postpartum women & $\begin{array}{c}\text { From the total, } 7.8 \% \text { were prescribed } \\
\text { antidepressants, while } 5 \% \text { have been } \\
\text { diagnosed with depression, percentages } \\
\text { which differ depending on the type of the } \\
\text { hormonal contraception. It should be noted } \\
\text { that the women had previously served in } \\
\text { the US army }\end{array}$ & {$[90]$} \\
\hline $\mathrm{HC}$ & 815,662 Swedish women & $\begin{array}{l}\text { The high CI (95\%) OR indicate a strong } \\
\text { correlation between psychotropic drug } \\
\text { usage among adolescents compared with } \\
\text { the older women }\end{array}$ & [91] \\
\hline
\end{tabular}


Table 2. Cont.

\begin{tabular}{|c|c|c|c|}
\hline Type of Drug & Number of Patients & Main Observations & Reference \\
\hline GnRHa & 29 women (agonist) & $\begin{array}{l}\text { GnRHa has been positively correlated with } \\
\text { a pronounced depression-like } \\
\text { symptomatology, analogue with anxiety, } \\
\text { but this have been considered an overlap of } \\
\text { the pre-existing condition in euthymic } \\
\text { participants according to the HAM-A, } \\
\text { HAM-D and VAS-A and VAS-D }\end{array}$ & [93] \\
\hline
\end{tabular}

CC-clomiphene citrate; PMS-premenstrual syndrome; hMG-human menopausal gonadotropin; HPG-hypothalamic-pituitary-gonadal; STAI-State-Trait Anxiety Inventory; OC-oral contraception; CD-Cyclicity Diagnoser; fMRI—Functional Magnetic Resonance Imaging; COC—combined oral contraception; CES-D—Center for Epidemiologic Studies Depression Scale; HC—hormonal contraception; MDD—major depression disorder; QIDS-16-Item Quick Inventory of Depressive Symptomatology; OR_odds ratio; CI-confidence interval; PCOS—polycystic ovary syndrome; Ais—Aromatase Inhibitors; MD—major depression; PHQ-9—Patient Health Questionnaire-9; GnRHa-gonadotropin-releasing hormone agosnists; HAM-A/-Hamilton Scales for Anxiety/Depression; VAS-A/D_Visual Analogue Scale for Anxiety/Depression.

It must be taken into consideration that in Table 2, we have focused only on those drugs usually administered for infertility with a known potential for a sside effect that include the promotion of a psychiatric disorder.

Unfortunately, very little is known regarding the side effect profile of infertility medication.

Thus, it can be concluded on the basis of the studies summarised in Table 2 that infertility drugs indeed exert antagonistic effects upon the neurohormonal axis by disrupting its normal functionality.

It is difficult for patients and clinicians to figure out which responses are psychological and which are caused by medication, but it is vital to identify the causes in order to determine the future measures.

\section{How Infertility and Associated Drugs Disrupt the HPA Axis?}

Infertility can have profound consequences on a person's psychology, often through the perception of losing control on one's life [94]. The issue of infertility can become centric to a relationship with anger and confusion replacing reason [95]. This is because an adults' progress and identity often resides with the desire to conceive [96]. Cousineau [97] extensively reviewed all the aspects surrounding the issues in relation to the cultural and social effects of infertility, along with the influence on marital status and decision making and the relevant psychological support. Infertility treatment puts a great deal of stress on a couple and as this can culminate in an attitude of resignation, and the aspiration to have a child is replaced by adoption or being child free [98].

Many couples find it difficult to adapt to this new trajectory, and often find it hard to acquire a new vision beyond this temporary crisis [99]. They must often make radical lifestyle adjustments, such as re-evaluating decisions surrounding career options, with other important aspirations often postponed [100]. Aside from the individual lifestyle upheaval, one must adapt to a rigorous medication program [101].

Infertility should not be viewed as a major impediment, but rather as an unplanned event. The literature highlights a broad array of causes for infertility. The ones that have been most emphasised lately are polycystic ovarian syndrome (PCOS) [102,103], hypothalamic dysfunctions [104], premature ovarian failure (POF) [105] and endometriosis [106]. However, rather than focussing on the organic aetiology behind infertility, we have decided to detail the associated neuropsychiatric comorbidities, given the fact that women are more prone to mixed anxiety-depressive disorders (MAAD) than men. This is why, in Table 3, we have summarised all the studies conducted between 2010-2020, focussing on large cohorts ( $\geq 1000$ patients per sample). 
Table 3. Associations between infertility and the predisposition for upcoming health issues.

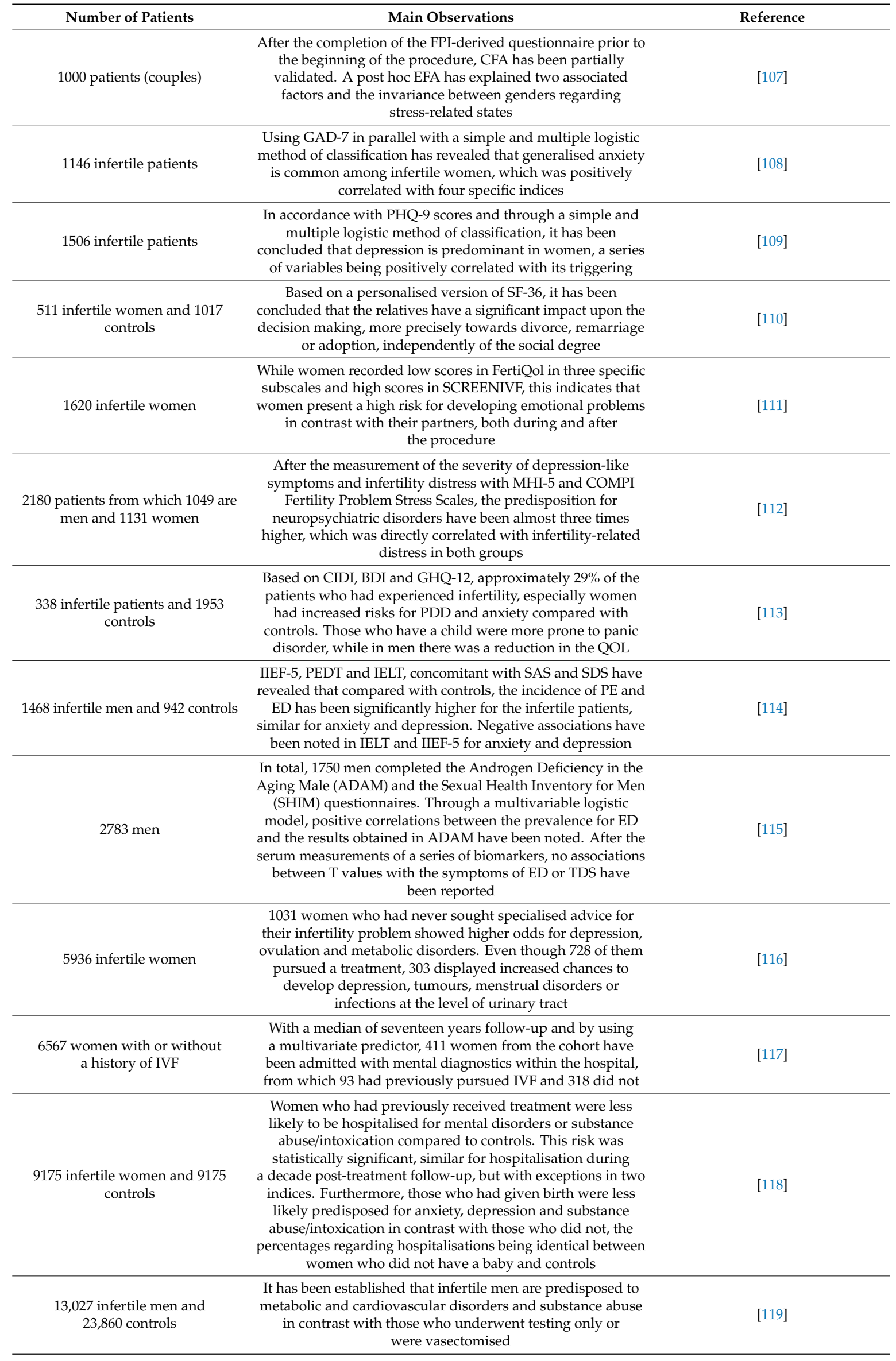


Table 3. Cont.

\begin{tabular}{|c|c|c|}
\hline Number of Patients & Main Observations & Reference \\
\hline 98,320 women & $\begin{array}{l}\text { When a pregnancy failed, women were at increased risk for } \\
\text { psychiatric disorders and substance abuse compared with the } \\
\text { women who gave birth after the infertility evaluation. No } \\
\text { significant differences have been noted regarding the } \\
\text { prevalence of anxiety, eating disorders or OCD }\end{array}$ & [120] \\
\hline $\begin{array}{l}\text { HUNT 2006-2008 } n=9200 \\
\text { womenHUNT } 1 \text { and HUNT } 2 n= \\
5873 \text { sub-fertile women and } \\
\text { HUNT } 2 n=12,987 \text { women }\end{array}$ & $\begin{array}{l}\text { North-Trøndelag Health Study has been one of the biggest } \\
\text { cross-sectional population-based studies designed to } \\
\text { determine the predisposition of CNS disorders. Nevertheless, } \\
\text { the results obtained are antithetical. No conclusive evidence } \\
\text { has been found in two of them to link the incidence of } \\
\text { infertility with the common mental health disorders, but the } \\
\text { third confirms the causality }\end{array}$ & [121-123] \\
\hline \multicolumn{3}{|c|}{$\begin{array}{l}\text { PFI-Fertility Problem Inventory; CFA-Confirmatory Factor Analysis; EFA-Exploratory Factor Analysis; } \\
\text { GAD-7-Generalized Anxiety Disorder-7; PHQ-9-Patient Health Questionnaire-9; SF-36-The Short Form } \\
\text { (36) Health Survey; FertiQol-The Fertility Quality of Life Questionnaire; MHI-5-Mental Health Inventory } \\
\text { 5; CIDI-Composite International Diagnostic Interview; BDI-Beck Depression Inventory; GHQ-12-The 12-item } \\
\text { General Health Questionnaire; PDD-Persistent Depressive Disorder; QOL-Quality Of Life; PE-Premature } \\
\text { ejaculation; ED-Erectile dysfunction; PEDT-PE Diagnostic Tool; IELT-Intravaginal Ejaculatory Latency Time; } \\
\text { IIEF-5-International Index of Erectile Function; SAS-Self-rating Anxiety Scale; SDS-Self-rating Depression Scale; } \\
\text { IVF-In Vitro Fertilisation; OCD-Obsessive-Compulsive Disorder; CNS-Central Nervous System. }\end{array}$} \\
\hline
\end{tabular}

\section{Conclusions}

The evidence presented in this manuscript suggests that the gut microflora has a profound and complex influence on the psychological profile of each individual. Moreover, changes in this integrative system may serve as a bridge to upcoming CNS disorders, whilst also having the potential to provoke gastrointestinal deficiencies in an early stage. Regarding the infertility medication and the overall "disease", this topic remains debatable, mainly because the number of studies is limited, but it is clear that it may disrupt the integrity of the GBA-HPA axes. However, an occurring dysbacteriosis not only gradually alters homeostasis, but also amplifies the chances to block entirely the effect of any infertility drug. On the other hand, the techniques dedicated to the restoration of the microbial communities have undergone a fulminant ascension lately but, like any therapy, some disorders have been omitted for unknown reasons, which is why additional studies will further aid our understanding.

Author Contributions: Writing-original draft, G.S., O.-D.I.; Conceptualization and Vizualization, A.C.; Methodology and Validation, B.D., R.M., D.G., E.A.; Formal analysis and Writing-review and editing, J.M., N.D., I.M. All authors have read and agreed to the published version of the manuscript.

Funding: A.C. is supported by a research grant for Young Teams offered by UEFISCDI Romania, no. PN-III-P1-1.1-TE-2016-1210, contract no. 58 from 02/05/2018, called "Complex study regarding the interactions between oxidative stress, inflammation and neurological manifestations in the pathophysiology of irritable bowel syndrome (animal models and human patients)".

Acknowledgments: Not applicable, with the exception of the research grant mentioned above.

Conflicts of Interest: The authors declare that they have no conflict of interest.

\section{References}

1. Ursell, L.K.; Metcalf, J.L.; Parfrey, L.W.; Knight, R. Defining the human microbiome. Nutr. Rev. 2012, 70 (Suppl. 1), S38-S44. [CrossRef] [PubMed]

2. Group, NIHHMPW; Peterson, J.; Garges, S.; Giovanni, M.; McInnes, P.; Wang, L.; Schloss, A.J.; Bonazzi, V.; McEwen, E.J.; Wetterstrand, A.K.; et al. The NIH Human Microbiome Project. Genome Res. 2009, 19, $2317-2323$. [PubMed]

3. Turnbaugh, P.J.; Ley, R.E.; Hamady, M.; Fraser-Liggett, C.M.; Knight, R.; Gordon, J.I. The human microbiome project. Nature 2007, 449, 804-810. [CrossRef] [PubMed]

4. Gilbert, J.A.; Blaser, M.J.; Caporaso, J.G.; Jansson, J.K.; Lynch, S.V.; Knight, R. Current understanding of the human microbiome. Nat. Med. 2018, 24, 392-400. [CrossRef]

5. Donaldson, G.P.; Lee, S.M.; Mazmanian, S.K. Gut biogeography of the bacterial microbiota. Nat. Rev. Microbiol. 2016, 14, 20-32. [CrossRef] 
6. Tropini, C.; Earle, K.A.; Huang, K.C.; Sonnenburg, J.L. The Gut Microbiome: Connecting Spatial Organization to Function. Cell Host Microbe 2017, 21, 433-442. [CrossRef]

7. Arumugam, M.; Raes, J.; Pelletier, E.; Le Paslier, D.; Yamada, T.; Mende, D.R.; Fernandes, R.G.; Tap, J.; Bruls, T.; Batto, M.-J.; et al. Enterotypes of the human gut microbiome. Nature 2011, 473, 174-180. [CrossRef]

8. Hollister, E.B.; Gao, C.; Versalovic, J. Compositional and functional features of the gastrointestinal microbiome and their effects on human health. Gastroenterology 2014, 146, 1449-1458. [CrossRef]

9. Rajilić-Stojanović, M.; de Vos, W.M. The first 1000 cultured species of the human gastrointestinal microbiota. FEMS Microbiol. Rev. 2014, 38, 996-1047. [CrossRef]

10. Consortium IHMP (iHMP) RN. The Integrative Human Microbiome Project. Nature 2019, 569, $641-648$.

11. Belkaid, Y.; Harrison, O.J. Homeostatic Immunity and the Microbiota. Immunity 2017, 46, 562-576. [CrossRef] [PubMed]

12. Bellono, N.W.; Bayrer, J.R.; Leitch, D.B.; Castro, J.; Zhang, C.; O’Donnell, T.A.; Brierley, M.S.; Ingraham, A.H.; Julius, D. Enterochromaffin Cells Are Gut Chemosensors that Couple to Sensory Neural Pathways. Cell 2017, 170, 185-198.e16. [CrossRef] [PubMed]

13. Rios, D.; Wood, M.B.; Li, J.; Chassaing, B.; Gewirtz, A.T.; Williams, I.R. Antigen sampling by intestinal M cells is the principal pathway initiating mucosal IgA production to commensal enteric bacteria. Mucosal Immunol. 2016, 9, 907-916. [CrossRef] [PubMed]

14. Yano, J.M.; Yu, K.; Donaldson, G.P.; Shastri, G.G.; Ann, P.; Ma, L.; Nagler, R.C.; Ismagilov, F.R.; Mazmanian, K.S.; Hsiao, E. Indigenous bacteria from the gut microbiota regulate host serotonin biosynthesis. Cell 2015, 161, $264-276$. [CrossRef]

15. Jandhyala, S.M.; Talukdar, R.; Subramanyam, C.; Vuyyuru, H.; Sasikala, M.; Nageshwar Reddy, D. Role of the normal gut microbiota. World J. Gastroenterol. 2015, 21, 8787-8803. [CrossRef]

16. Chow, J.; Lee, S.M.; Shen, Y.; Khosravi, A.; Mazmanian, S.K. Host-bacterial symbiosis in health and disease. Adv. Immunol. 2010, 107, 243-274.

17. Appleton, J. The Gut-Brain Axis: Influence of Microbiota on Mood and Mental Health. Integr. Med. (Encinitas) 2018, 17, 28-32.

18. Sekirov, I.; Finlay, B.B. The role of the intestinal microbiota in enteric infection. J. Physiol. 2009, 587, 4159-4167. [CrossRef]

19. Zmora, N.; Suez, J.; Elinav, E. You are what you eat: Diet, health and the gut microbiota. Nat. Rev. Gastroenterol. Hepatol. 2019, 16, 35-56. [CrossRef]

20. Becattini, S.; Taur, Y.; Pamer, E.G. Antibiotic-Induced Changes in the Intestinal Microbiota and Disease. Trends Mol. Med. 2016, 22, 458-478. [CrossRef]

21. Minot, S.; Sinha, R.; Chen, J.; Li, H.; Keilbaugh, S.A.; Wu, G.D.; Lewis, D.J.; Bushman, D.F. The human gut virome: Inter-individual variation and dynamic response to diet. Genome Res. 2011, 21, 1616-1625. [CrossRef]

22. Van Schaik, W. The human gut resistome. Philos. Trans. R. Soc. Lond. B Biol. Sci. 2015, 370, 20140087. [CrossRef]

23. Monda, V.; Villano, I.; Messina, A.; Valenzano, A.; Esposito, T.; Moscatelli, F.; Viggiano, A.; Cibelli, G.; Cheffi, S.; Monda, M.; et al. Exercise Modifies the Gut Microbiota with Positive Health Effects. Oxid. Med. Cell Longev. 2017, 2017, 3831972. [CrossRef] [PubMed]

24. Goodrich, J.K.; Davenport, E.R.; Waters, J.L.; Clark, A.G.; Ley, R.E. Cross-species comparisons of host genetic associations with the microbiome. Science 2016, 352, 532-535. [CrossRef]

25. Hayashi, H.; Takahashi, R.; Nishi, T.; Sakamoto, M.; Benno, Y. Molecular analysis of jejunal, ileal, caecal and recto-sigmoidal human colonic microbiota using $16 \mathrm{~S}$ rRNA gene libraries and terminal restriction fragment length polymorphism. J. Med. Microbiol. 2005, 54, 1093-1101. [CrossRef] [PubMed]

26. Krishnan, S.; Alden, N.; Lee, K. Pathways and functions of gut microbiota metabolism impacting host physiology. Curr. Opin. Biotechnol. 2015, 36, 137-145. [CrossRef] [PubMed]

27. Levy, M.; Blacher, E.; Elinav, E. Microbiome, metabolites and host immunity. Curr. Opin. Microbiol. 2017, 35, 8-15. [CrossRef]

28. Robertson, R.C.; Manges, A.R.; Finlay, B.B.; Prendergast, A.J. The Human Microbiome and Child Growth First 1000 Days and Beyond. Trends Microbiol. 2019, 27, 131-147. [CrossRef]

29. Collado, M.C.; Rautava, S.; Aakko, J.; Isolauri, E.; Salminen, S. Human gut colonisation may be initiated in utero by distinct microbial communities in the placenta and amniotic fluid. Sci. Rep. 2016, 6, 23129. [CrossRef] 
30. Aagaard, K.; Ma, J.; Antony, K.M.; Ganu, R.; Petrosino, J.; Versalovic, J.L. The Placenta Harbors a Unique Microbiome. Sci. Transl. Med. 2014, 6, 237ra65. [CrossRef]

31. Makino, H.; Kushiro, A.; Ishikawa, E.; Kubota, H.; Gawad, A.; Sakai, T.; Oishi, K.; Martin, R.; Ben-Amor, K.; Knol, J.; et al. Mother-to-infant transmission of intestinal bifidobacterial strains has an impact on the early development of vaginally delivered infant's microbiota. PLoS ONE 2013, 8, e78331. [CrossRef] [PubMed]

32. Rautava, S.; Collado, M.C.; Salminen, S.; Isolauri, E. Probiotics Modulate Host-Microbe Interaction in the Placenta and Fetal Gut: A Randomized, Double-Blind, Placebo-Controlled Trial. Neonatology 2012, 102, 178-184. [CrossRef] [PubMed]

33. Lauder, A.P.; Roche, A.M.; Sherrill-Mix, S.; Bailey, A.; Laughlin, A.L.; Bittinger, K.; Leite, R.; Elovitz, A.M.; Parry, S.; Bushman, D.F. Comparison of placenta samples with contamination controls does not provide evidence for a distinct placenta microbiota. Microbiome 2016, 4, 29. [CrossRef] [PubMed]

34. De Goffau, M.C.; Lager, S.; Sovio, U.; Gaccioli, F.; Cook, E.; Peacock, S.J.; Parkhill, J.; Charnock-Jones, S.D.; Smith, S.C.G. Human placenta has no microbiome but can contain potential pathogens. Nature 2019, 572, 329-334. [CrossRef] [PubMed]

35. Stout, M.J.; Conlon, B.; Landeau, M.; Lee, I.; Bower, C.; Zhao, Q.; Roehl, A.K.; Nelson, M.D.; Macones, A.G.; Mysorekar, U.I. Identification of intracellular bacteria in the basal plate of the human placenta in term and preterm gestations. Am. J. Obstet. Gynecol. 2013, 208, 226.e1-226.e7. [CrossRef] [PubMed]

36. Agrawal, V.; Hirsch, E. Intrauterine infection and preterm labor. Semin. Fetal. Neonatal. Med. 2012, 17, 12-19. [CrossRef] [PubMed]

37. Ananth, C.; Oyelese, Y.; Srinivas, N.; Yeo, L.; Vintzileos, A. Preterm Premature Rupture of Membranes, Intrauterine Infection, and Oligohydramnios. Obstet. Gynecol. 2004, 104, 71-77. [CrossRef]

38. Steel, J.H.; Malatos, S.; Kennea, N.; Edwards, A.D.; Miles, L.; Duggan, P.; Reynold, R.P.; Feldman, G.R.; Sullivan, F.H.M. Bacteria and Inflammatory Cells in Fetal Membranes Do Not Always Cause Preterm Labor. Pediatr. Res. 2005, 57, 404-411. [CrossRef]

39. Jones, H.E.; Harris, K.A.; Azizia, M.; Bank, L.; Carpenter, B.; Hartley, J.C.; Klein, N.; Peebles, D. Differing prevalence and diversity of bacterial species in fetal membranes from very preterm and term labor. PLoS ONE 2009, 4, e8205. [CrossRef]

40. Ardissone, A.N.; de la Cruz, D.M.; Davis-Richardson, A.G.; Rechcigl, K.T.; Li, N.; Drew, J.C.; Torrazzam, R.L.; Sharma, R.; Hudaks, L.M.; Triplett, W.E.; et al. Meconium microbiome analysis identifies bacteria correlated with premature birth. PLoS ONE 2014, 9, e90784. [CrossRef]

41. Mshvildadze, M.; Neu, J.; Shuster, J.; Theriaque, D.; Li, N.; Mai, V. Intestinal microbial ecology in premature infants assessed with non-culture-based techniques. J. Pediatr. 2010, 156, 20-25. [CrossRef] [PubMed]

42. Hu, J.; Nomura, Y.; Bashir, A.; Fernandez-Hernandez, H.; Itzkowitz, S.; Pei, Z.; Stone, J.; Luodon, H.; Peter, I. Diversified microbiota of meconium is affected by maternal diabetes status. PLoS ONE 2013, 8, e78257. [CrossRef] [PubMed]

43. Jiménez, E.; Marín, M.L.; Martín, R.; Odriozola, J.M.; Olivares, M.; Xaus, J.; Fernández, L.; Rodríguez, M.J. Is meconium from healthy newborns actually sterile? Res. Microbiol. 2008, 159, 187-193. [CrossRef] [PubMed]

44. Hansen, R.; Scott, K.P.; Khan, S.; Martin, J.C.; Berry, S.H.; Stevenson, M.; Okpapi, A.; Munro, J.M.; Hold, L.G. First-Pass Meconium Samples from Healthy Term Vaginally-Delivered Neonates: An Analysis of the Microbiota. PLoS ONE 2015, 10, e0133320. [CrossRef] [PubMed]

45. DiGiulio, D.B.; Romero, R.; Amogan, H.P.; Kusanovic, J.P.; Bik, E.M.; Gotsch, F.; Kim, J.C.; Erez, O.; Edwin, S.; Relman, A.D. Microbial prevalence, diversity and abundance in amniotic fluid during preterm labor: A molecular and culture-based investigation. PLoS ONE 2008, 3, e3056. [CrossRef] [PubMed]

46. Shao, Y.; Forster, S.C.; Tsaliki, E.; Vervier, K.; Strang, A.; Simpson, N.; Kuman, N.; Stares, D.M.; Rodger, A.; Brocklehurst, P.; et al. Stunted microbiota and opportunistic pathogen colonization in caesarean-section birth. Nature 2019, 574, 117-121. [CrossRef] [PubMed]

47. Gasparrini, A.J.; Wang, B.; Sun, X.; Kennedy, E.A.; Hernandez-Leyva, A.; Ndao, I.M.; Tarr, I.P.; Warner, B.B.; Dantas, G. Persistent metagenomic signatures of early-life hospitalization and antibiotic treatment in the infant gut microbiota and resistome. Nat. Microbiol. 2019, 4, 2285-2297. [CrossRef]

48. Turnbaugh, P.J.; Quince, C.; Faith, J.J.; McHardy, A.C.; Yatsunenko, T.; Niazi, F.; Affourtit, J.; Egholm, M.; Henrissat, B.; Knight, R.; et al. Organismal, genetic, and transcriptional variation in the deeply sequenced gut microbiomes of identical twins. Proc. Natl. Acad. Sci. USA 2010, 107, 7503-7508. [CrossRef] 
49. Goodrich, J.K.; Davenport, E.R.; Beaumont, M.; Jackson, M.A.; Knight, R.; Ober, C.; Spector, D.T.; Bell, T.J.; Clark, G.A.; Ley, E.R. Genetic Determinants of the Gut Microbiome in UK Twins. Cell Host Microbe 2016, 19, 731-743. [CrossRef]

50. Lee, S.; Sung, J.; Lee, J.; Ko, G. Comparison of the gut microbiotas of healthy adult twins living in South Korea and the United States. Appl. Environ. Microbiol. 2011, 77, 7433-7437. [CrossRef]

51. Schloss, P.D.; Iverson, K.D.; Petrosino, J.F.; Schloss, S.J. The dynamics of a family's gut microbiota reveal variations on a theme. Microbiome 2014, 2, 25. [CrossRef] [PubMed]

52. Kato, K.; Ishida, S.; Tanaka, M.; Mitsuyama, E.; Xiao, J.-Z.; Odamaki, T. Association between functional lactase variants and a high abundance of Bifidobacterium in the gut of healthy Japanese people. PLoS ONE 2018, 13, e0206189. [CrossRef] [PubMed]

53. Liebert, A.; López, S.; Jones, B.L.; Montalva, N.; Gerbault, P.; Lau, W.; Thomas, G.M.; Bradman, N.; Maniatis, N.; Swallow, M.D. World-wide distributions of lactase persistence alleles and the complex effects of recombination and selection. Hum. Genet. 2017, 136, 1445-1453. [CrossRef] [PubMed]

54. Itan, Y.; Jones, B.L.; Ingram, C.J.E.; Swallow, D.M.; Thomas, M.G. A worldwide correlation of lactase persistence phenotype and genotypes. BMC Evol. Biol. 2010, 10, 36. [CrossRef] [PubMed]

55. Mattar, R.; de Campos Mazo, D.F.; Carrilho, F.J. Lactose intolerance: Diagnosis, genetic, and clinical factors. Clin. Exp. Gastroenterol. 2012, 5, 113-121. [CrossRef] [PubMed]

56. Odamaki, T.; Bottacini, F.; Mitsuyama, E.; Yoshida, K.; Kato, K.; Xiao, J.; van Sinderen, D. Author Correction: Impact of a bathing tradition on shared gut microbes among Japanese families. Sci. Rep. 2020, 10, 2280. [CrossRef]

57. Odamaki, T.; Bottacini, F.; Kato, K.; Mitsuyama, E.; Yoshida, K.; Horigome, A.; Xiao, Z.J. Genomic diversity and distribution of Bifidobacterium longum subsp. longum across the human lifespan. Sci. Rep. 2018, 8, 85. [CrossRef]

58. Laursen, M.F.; Zachariassen, G.; Bahl, M.I.; Bergström, A.; Høst, A.; Michaelsen, K.F.; Licht, R.T. Having older siblings is associated with gut microbiota development during early childhood. BMC Microbiol. 2015, 15, 154. [CrossRef]

59. Laursen, M.F.; Laursen, R.P.; Larnkjær, A.; Mølgaard, C.; Michaelsen, K.F.; Frøkiær, H.; Bahl, I.M.; Licht, R.T. Faecalibacterium Gut Colonization Is Accelerated by Presence of Older Siblings. MSphere 2017, 2, e00448-17. [CrossRef]

60. Dill-McFarland, K.A.; Tang, Z.-Z.; Kemis, J.H.; Kerby, R.L.; Chen, G.; Palloni, A.; Sorenson, T.; Rey, E.F.; Herd, P. Close social relationships correlate with human gut microbiota composition. Sci. Rep. 2019, 9, 703. [CrossRef]

61. Voigt, A.Y.; Costea, P.I.; Kultima, J.R.; Li, S.S.; Zeller, G.; Sunagawa, S.; Bork, P. Temporal and technical variability of human gut metagenomes. Genome Biol. 2015, 16, 73. [CrossRef] [PubMed]

62. Buttó, L.F.; Haller, D. Dysbiosis in intestinal inflammation: Cause or consequence. Int. J. Med. Microbiol. 2016, 306, 302-309. [CrossRef] [PubMed]

63. Balmus, I.-M.; Ilie-Dumitru, O.; Ciobica, A.; Cojocariu, R.-O.; Stanciu, C.; Trifan, A.; Cimpeanu, M.; Cimpeanu, C.; Gorgan, L. Irritable Bowel Syndrome between Molecular Approach and Clinical Expertise-Searching for Gap Fillers in the Oxidative Stress Way of Thinking. Medicina 2020, 56, 38. [CrossRef] [PubMed]

64. Mawdsley, J.E.; Rampton, D.S. Psychological stress in IBD: New insights into pathogenic and therapeutic implications. Gut 2005, 54, 1481-1491. [CrossRef] [PubMed]

65. Ilie, O.-D.; Ciobica, A.; McKenna, J.; Doroftei, B.; Mavroudis, I. Minireview on the Relations between Gut Microflora and Parkinson's Disease: Further Biochemical (Oxidative Stress), Inflammatory, and Neurological Particularities. Oxid. Med. Cell Longev. 2020, 2020, 4518023. [CrossRef]

66. Lefter, R.; Ciobica, A.; Timofte, D.; Stanciu, C.; Trifan, A. A Descriptive Review on the Prevalence of Gastrointestinal Disturbances and Their Multiple Associations in Autism Spectrum Disorder. Medicina 2019, 56, 11. [CrossRef]

67. Hritcu, L.; Padurariu, M.; Ciobica, A.; Horhogea, C.; Spataru, C.; Spataru, C.; Burtan, L.; Stefanescu, C. Serum Cortisol Levels Modifications in Patients with Depression and Irritable Bowel Syndrome. Rev. Chim. 2019, 70, 3383-3386. [CrossRef]

68. Gavril, R.; Hritcu, L.; Padurariu, M.; Ciobica, A.; Horhogea, C.; Stefanescu, G.; Spataru, C.M.; Straulea, C.; Stefanescu, C. Preliminary Study on the Correlations Between Oxytocin Levels and Irritable Bowel Syndrome in Patients with Depression. Rev. Chim. 2019, 70, 2204-2206. [CrossRef] 
69. Hritcu, L.; Dumitru, I.; Padurariu, M.; Ciobica, A.; Spataru, C.; Spataru, C.; Stefanescu, G.; Stefanescu, C.; Gabos-Grecu, C. The Modulation of Oxytocin and Cortisol Levels in Major Depression Disorder and Irritable Bowel Syndrome. Rev. Chim. 2020, 71, 150-154. [CrossRef]

70. Verna, E.C.; Lucak, S. Use of probiotics in gastrointestinal disorders: What to recommend? Ther. Adv. Gastroenterol. 2010, 3, 307-319. [CrossRef]

71. Wilkins, T.; Sequoia, J. Probiotics for Gastrointestinal Conditions: A Summary of the Evidence. Am. Fam. Physician 2017, 96, 170-178. [PubMed]

72. West, R.R.; Roberts, E.; Sichel, L.S.; Sichel, J. Improvements in Gastrointestinal Symptoms among Children with Autism Spectrum Disorder Receiving the Delpro ${ }^{\circledR}$ Probiotic and Immunomodulator Formulation. J. Probiotics Heal 2013. [CrossRef]

73. Tomova, A.; Husarova, V.; Lakatosova, S.; Bakos, J.; Vlkova, B.; Babinska, K.; Ostatnikova, D. Gastrointestinal microbiota in children with autism in Slovakia. Physiol. Behav. 2015, 138, 179-187. [CrossRef] [PubMed]

74. Pärtty, A.; Kalliomäki, M.; Wacklin, P.; Salminen, S.; Isolauri, E. A possible link between early probiotic intervention and the risk of neuropsychiatric disorders later in childhood: A randomized trial. Pediatr. Res 2015, 77, 823-828. [CrossRef]

75. Sandler, R.; Finegold, S.; Bolte, E.; Buchanan, C.; Maxwell, A.P.; Väisänen, M.; Nelson, N.M.; Wexler, H.M. Short-Term Benefit From Oral Vancomycin Treatment of Regressive-Onset Autism. J. Child. Neurol. 2000, 15, 429-435. [CrossRef]

76. Shaaban, S.Y.; El Gendy, Y.G.; Mehanna, N.S.; El-Senousy, W.M.; El-Feki, H.S.A.; Saad, K.; El-Asheer, M.O. The role of probiotics in children with autism spectrum disorder: A prospective, open-label study. Nutr. Neurosci. 2018, 21, 676-681. [CrossRef]

77. Parracho, H.M.R.T.; Gibson, G.R.; Knott, F.; Bosscher, D.; Kleerebezem, M.; Mccartney, A. A double-blind, placebo-controlled, crossover-designed probiotic feeding study in children diagnosed with autistic spectrum disorders. Int. J. Probiotics Prebiotics 2010, 5, 69-74.

78. Grossi, E.; Melli, S.; Dunca, D.; Terruzzi, V. Unexpected improvement in core autism spectrum disorder symptoms after long-term treatment with probiotics. SAGE Open Med. Case Rep. 2016, 4, $2050313 X 16666231$. [CrossRef]

79. Dickerson, F.B.; Stallings, C.; Origoni, A.; Katsafanas, E.; Savage, C.L.G.; Schweinfurth, L.A.B.; Goga, J.; Khushalani, S.; Yolken, H.R. Effect of probiotic supplementation on schizophrenia symptoms and association with gastrointestinal functioning: A randomized, placebo-controlled trial. Prim. Care Companion. CNS Disord. 2014, 16, PCC.13m01579. [CrossRef]

80. Tomasik, J.; Yolken, R.H.; Bahn, S.; Dickerson, F.B. Immunomodulatory Effects of Probiotic Supplementation in Schizophrenia Patients: A Randomized, Placebo-Controlled Trial. Biomark. Insights 2015, 10, 47-54. [CrossRef]

81. Severance, E.G.; Gressitt, K.L.; Stallings, C.R.; Katsafanas, E.; Schweinfurth, L.A.; Savage, C.L.G.; Adamos, B.M.; Sweeney, M.K.; Origoni, E.A.; Khushalani, S. Probiotic normalization of Candida albicans in schizophrenia: A randomized, placebo-controlled, longitudinal pilot study. Brain Behav. Immun. 2017, 62, 41-45. [CrossRef] [PubMed]

82. Sirota, I.; Zarek, S.M.; Segars, J.H. Potential influence of the microbiome on infertility and assisted reproductive technology. Semin. Reprod. Med. 2014, 32, 35-42. [CrossRef] [PubMed]

83. Blenner, J.L. Clomiphene-lnduced Mood Swings. J. Obstet. Gynecol. Neonatal. Nurs. 1991, 20, $321-327$. [CrossRef] [PubMed]

84. Aussedat, M.; Jean-Louis, J.; Brochet, O.D.M.-S. Clomiphene for the Treatment of Male Infertility: A Case Report of Mood Change and a Literature Overview. Curr. Drug. Saf. 2017, 12, 208-215. [CrossRef]

85. Choi, S.-H.; Shapiro, H.; Robinson, G.E.; Irvine, J.; Neuman, J.; Rosen, B.; Murphy, J.; Swewart, D. Psychological side-effects of clomiphene citrate and human menopausal gonadotrophin. J. Psychosom. Obstet. Gynecol. 2005, 26, 93-100. [CrossRef]

86. Gingnell, M.; Engman, J.; Frick, A.; Moby, L.; Wikström, J.; Fredrikson, M.; Sundström-Poromaa, I. Oral contraceptive use changes brain activity and mood in women with previous negative affect on the pill-A double-blinded, placebo-controlled randomized trial of a levonorgestrel-containing combined oral contraceptive. Psychoneuroendocrinology 2013, 38, 1133-1144. [CrossRef]

87. O'Connell, K.; Davis, A.R.; Kerns, J. Oral contraceptives: Side effects and depression in adolescent girls. Contraception 2007, 75, 299-304. [CrossRef] 
88. Skovlund, C.W.; Mørch, L.S.; Kessing, L.V.; Lidegaard, Ø. Association of Hormonal Contraception With Depression. JAMA Psychiatry 2016, 73, 1154-1162. [CrossRef]

89. Young, E.A.; Kornstein, S.G.; Harvey, A.T.; Wisniewski, S.R.; Barkin, J.; Fava, M.; Trivedi, H.M.; Rush, J.A. Influences of hormone-based contraception on depressive symptoms in premenopausal women with major depression. Psychoneuroendocrinology 2007, 32, 843-853. [CrossRef]

90. Roberts, T.A.; Hansen, S. Association of Hormonal Contraception with depression in the postpartum period. Contraception 2017, 9, 446-452. [CrossRef]

91. Zettermark, S.; Perez Vicente, R.; Merlo, J. Hormonal contraception increases the risk of psychotropic drug use in adolescent girls but not in adults: A pharmacoepidemiological study on 800000 Swedish women. PLoS ONE 2018, 13, e0194773. [CrossRef] [PubMed]

92. Evans-Hoeker, E.A.; Eisenberg, E.; Diamond, M.P.; Legro, R.S.; Alvero, R.; Coutifaris, C.; Casson, R.P.; Christman, M.G.; Hansen, R.K.; Zhang, H.; et al. Major depression, antidepressant use, and male and female fertility. Fertil. Steril. 2018, 109, 879-887. [CrossRef] [PubMed]

93. Toren, P.; Dor, J.; Mester, R.; Mozes, T.; Blumensohn, R.; Rehavi, M.; Weizman, A. Depression in women treated with a gonadotropinreleasing hormone agonist. Biol. Psychiatry 1996, 39, 378-382. [CrossRef]

94. Wallach, E.E.; Seibel, M.M.; Taymor, M.L. Emotional aspects of infertility. Fertil. Steril. 1982, 37, $137-145$. [CrossRef]

95. Nichols, W.C.; Pace-Nichols, M.A. Childless married couples. In Handbook of Family Development and Intervention; John Wiley \& Sons Inc.: Hoboken, NJ, USA, 2000; pp. 171-188.

96. Greenfeld, D.A. The course of infertility: Immediate and long-term reactions. Sess Psychother. Pract. 1996, 2, 5-16. [CrossRef]

97. Cousineau, T.M.; Domar, A.D. Psychological impact of infertility. Best Pract. Res. Clin. Obstet. Gynaecol. 2007, 21, 293-308. [CrossRef]

98. Greil, A.; McQuillan, J.; Slauson-Blevins, K. The Social Construction of Infertility. Soc. Compass 2011, 5, 736-746. [CrossRef]

99. Schmidt, L. Psychosocial Consequences of Infertility and Treatment BT-Reproductive Endocrinology and Infertility: Integrating Modern Clinical and Laboratory Practice; Carrell, D.T., Peterson, C.M., Eds.; Springer: New York, NY, USA, 2010; pp. 93-100.

100. Verhaak, C.M.; Smeenk, J.M.J.; Evers, A.W.M.; Kremer, J.A.M.; Kraaimaat, F.W.; Braat, D.D.M. Women's emotional adjustment to IVF: A systematic review of 25 years of research. Hum. Reprod. Update 2006, 13, 27-36. [CrossRef]

101. Boivin, J. A review of psychosocial interventions in infertility. Soc. Sci. Med. 2003, 57, 2325-2341. [CrossRef]

102. Barry, J.A.; Kuczmierczyk, A.R.; Hardiman, P.J. Anxiety and depression in polycystic ovary syndrome: A systematic review and meta-analysis. Hum. Reprod. 2011, 26, 2442-2451. [CrossRef]

103. Cooney, L.G.; Lee, I.; Sammel, M.D.; Dokras, A. High prevalence of moderate and severe depressive and anxiety symptoms in polycystic ovary syndrome: A systematic review and meta-analysis. Hum. Reprod. 2017, 32, 1075-1091. [CrossRef] [PubMed]

104. Meczekalski, B.; Katulski, K.; Czyzyk, A.; Podfigurna-Stopa, A.; Maciejewska-Jeske, M. Functional hypothalamic amenorrhea and its influence on women's health. J. Endocrinol. Invest. 2014, 37, 1049-1056. [CrossRef] [PubMed]

105. Rafique, S.; Sterling, E.W.; Nelson, L.M. A new approach to primary ovarian insufficiency. Obstet. Gynecol. Clin. North Am. 2012, 39, 567-586. [CrossRef] [PubMed]

106. Laganà, A.S.; La Rosa, V.L.; Rapisarda, A.M.C.; Valenti, G.; Sapia, F.; Chiofalo, B.; Rossetti, D.; Frangež, B.H.; Bokan, V.E.; Vitale, G.S. Anxiety and depression in patients with endometriosis: Impact and management challenges. Int. J. Womens Health 2017, 9, 323-330. [CrossRef] [PubMed]

107. Donarelli, Z.; Gullo, S.; Lo Coco, G.; Marino, A.; Scaglione, P.; Volpes, A.; Allegra, A. Assessing infertility-related stress: The factor structure of the Fertility Problem Inventory in Italian couples undergoing infertility treatment. J. Psychosom. Obstet. Gynecol. 2015, 36, 58-65. [CrossRef]

108. Omani-Samani, R.; Ghaheri, A.; Navid, B.; Sepidarkish, M.; Maroufizadeh, S. Prevalence of generalized anxiety disorder and its related factors among infertile patients in Iran: A cross-sectional study. Health Qual. Life Outcomes 2018, 16, 129. [CrossRef] [PubMed] 
109. Omani-Samani, R.; Maroufizadeh, S.; Almasi-Hashiani, A.; Amini, P. Prevalence of depression and its determinant factors among infertile patients in Iran based on the PHQ-. Middle East Fertil. Soc. J. 2018, 23, 460-463. [CrossRef]

110. Amiri, M.; Khosravi, A.; Chaman, R.; Sadeghi, Z.; Raei, M.; Jahanitiji, M.; Mehrabian, F. Social Consequences of Infertility on Families in Iran. Glob. J. Health Sci. 2015, 8, 89-95. [CrossRef]

111. Huppelschoten, A.G.; van Dongen, A.J.C.M.; Verhaak, C.M.; Smeenk, J.M.J.; Kremer, J.A.M.; Nelen, W.L.D.M. Differences in quality of life and emotional status between infertile women and their partners. Hum. Reprod. 2013, 28, 2168-2176. [CrossRef]

112. Peterson, B.D.; Sejbaek, C.S.; Pirritano, M.; Schmidt, L. Are severe depressive symptoms associated with infertility-related distress in individuals and their partners? Hum. Reprod. 2013, 29, 76-82. [CrossRef]

113. Klemetti, R.; Raitanen, J.; Sihvo, S.; Saarni, S.; Koponen, P. Infertility, mental disorders and well-being-A nationwide survey. Acta Obstet. Gynecol. Scand. 2010, 89, 677-682. [CrossRef] [PubMed]

114. Gao, J.; Zhang, X.; Su, P.; Liu, J.; Shi, K.; Hao, Z.; Zhou, J.; Liang, C. Relationship between Sexual Dysfunction and Psychological Burden in Men with Infertility: A Large Observational Study in China. J. Sex Med. 2013, 10, 1935-1942. [CrossRef] [PubMed]

115. Satkunasivam, R.; Ordon, M.; Hu, B.; Mullen, B.; Lo, K.; Grober, E.; Jarvi, K. Hormone abnormalities are not related to the erectile dysfunction and decreased libido found in many men with infertility. Fertil. Steril. 2014, 101, 1594-1598. [CrossRef] [PubMed]

116. Herbert, D.L.; Lucke, J.C.; Dobson, A.J. Depression: An emotional obstacle to seeking medical advice for infertility. Fertil. Steril. 2010, 94, 1817-1821. [CrossRef]

117. Stewart, L.M.; Holman, C.D.J.; Semmens, J.B.; Preen, D.; Mai, Q.; Hart, R. Hospital mental health admissions in women after unsuccessful infertility treatment and in vitro fertilization: An Australian population-based cohort study. PLoS ONE 2015, 10, e0120076. [CrossRef]

118. Yli-Kuha, A.-N.; Gissler, M.; Klemetti, R.; Luoto, R.; Koivisto, E.; Hemminki, E. Psychiatric disorders leading to hospitalization before and after infertility treatments. Hum. Reprod. 2010, 25, 2018-2023. [CrossRef]

119. Eisenberg, M.L.; Li, S.; Cullen, M.R.; Baker, L.C. Increased risk of incident chronic medical conditions in infertile men: Analysis of United States claims data. Fertil. Steril. 2016, 105, 629-636. [CrossRef]

120. Baldur-Felskov, B.; Kjaer, S.K.; Albieri, V.; Steding-Jessen, M.; Kjaer, T.; Johansen, C.; Dalton, O.S.; Jensen, A. Psychiatric disorders in women with fertility problems: Results from a large Danish register-based cohort study. Hum. Reprod. 2012, 28, 683-690. [CrossRef]

121. Biringer, E.; Kessler, U.; Mykletun, A. PW01-98-No predictive value of anxiety- and depression symptoms for sub- or infertility. Eur. Psychiatry 2010, 25, 1529. [CrossRef]

122. Biringer, E.; Kessler, U.; Howard, L.M.; Pasupathy, D.; Mykletun, A. Anxiety, depression and probability of live birth in a cohort of women with self-reported infertility in the HUNT 2 Study and Medical Birth Registry of Norway. J. Psychosom. Res. 2018, 113, 1-7. [CrossRef]

123. Rostad, B.; Schmidt, L.; Sundby, J.; Schei, B. Infertility experience and health differentials-A population-based comparative study on infertile and non-infertile women (the HUNT Study). Acta Obstet. Gynecol. Scand. 2014, 93, 757-764. [CrossRef] [PubMed]

(C) 2020 by the authors. Licensee MDPI, Basel, Switzerland. This article is an open access article distributed under the terms and conditions of the Creative Commons Attribution (CC BY) license (http://creativecommons.org/licenses/by/4.0/). 